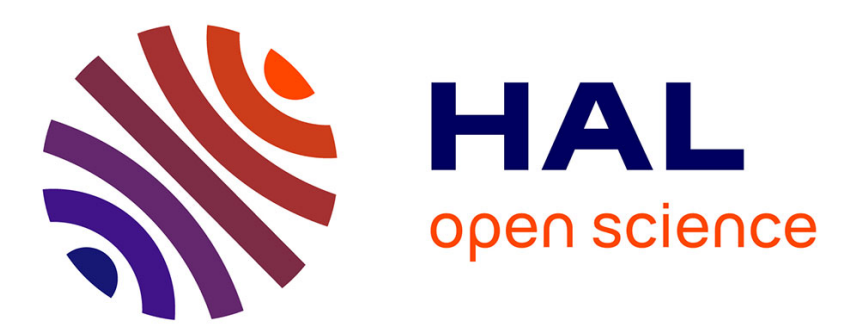

\title{
The Bt Brinjal Case: The First Legal Action Against Monsanto and Its Indian Collaborators for Biopiracy
}

\author{
Walid Abdelgawad
}

\section{To cite this version:}

Walid Abdelgawad. The Bt Brinjal Case: The First Legal Action Against Monsanto and Its Indian Collaborators for Biopiracy. Biotechnology Law Report, 2012, 31 (2), pp.136. 10.1089/blr.2012.9926 . hal-01131401

\author{
HAL Id: hal-01131401 \\ https://hal.science/hal-01131401
}

Submitted on 13 Mar 2015

HAL is a multi-disciplinary open access archive for the deposit and dissemination of scientific research documents, whether they are published or not. The documents may come from teaching and research institutions in France or abroad, or from public or private research centers.
L'archive ouverte pluridisciplinaire HAL, est destinée au dépôt et à la diffusion de documents scientifiques de niveau recherche, publiés ou non, émanant des établissements d'enseignement et de recherche français ou étrangers, des laboratoires publics ou privés. 


\title{
The Bt Brinjal Case: The First Legal Action Against Monsanto and Its Indian Collaborators for Biopiracy
}

\author{
By WALID ABDELGAWAD*
}

In an unprecedented case, the National Biodiversity Authority of India (NBA), a statutory body set up under the Biological Diversity Act 2002 (available at http://www.genecampaign.org/home/Biological\%20 Diversity\%20Act\%202002.pdf) to regulate access to and use of biological resources, decided to initiate a legal action for biopiracy against the U.S. transnational seed company Monsanto and its Indian collaborators. The aim of these proceedings was to denounce the use by these entities of indigenous varieties of brinjal to develop their genetically modified eggplant species, Bt Brinjal, without prior authorization.

"B IOPIRACY" GENERALLY REFERS TO illegal appropriation of biological diversity and the traditional knowledge of local communities from developing countries by multinational corporations and research institutions. ${ }^{1}$ This definition mainly takes two shapes: (1) access and use of biological material or traditional knowledge without the authorization of the country of origin and indigenous communities that hold and develop these resources; and/or (2) lack of benefit sharing, or unjust and unfair sharing of benefits, with the countries and communities who provided resources. These forms of biopiracy are expressly prohibited by Articles 15 and $8(\mathrm{j})$ of the Convention of Biological Diversity (CBD) $1992^{2}$ and, more recently, the Nagoya Protocol on access and benefit sharing adopted by the Conference of the Parties to the CBD at its tenth meeting on 29 October 2010. ${ }^{3}$ At the national level, many developing countries have adopted national legislation regulating access to their genetic resources and requiring benefit sharing in accordance with the principles of the CBD such as, for example, the Biological Diversity Act, 2002 in India. ${ }^{4}$ India, a country of vast biodiversity areas, is one of the ten megadiverse countries of the world, accounting for $7.8 \%$ of the global recorded species. ${ }^{5}$

In the last decades, famous biopiracy cases concerned disputed American or European patents granted for Indian plants and traditional knowledge: Curcuma, Neem,

*Lecturer at Burgundy University (France), CREDESPO. and Basmati Rice. ${ }^{6}$ Unlike these examples, in the current $B t$ brinjal case, foreign and Indian corporations and universities have been for the first time accused of biopiracy for violating the Biological Diversity Act in India.

After explaining framework in the $B t$ brinjal case, this paper analyzes the legal allegations related to the violations of the Biological Diversity Act by Monsanto

${ }^{1}$ See generally Vandana Shiva (1997), Biopiracy, The Plunder of Nature and Knowledge, South End Press, Cambridge; Ikechi Mgbeoji (2006), Global Biopiracy: Patents, Plants, and Indigenous Knowledge, University of British Columbia, UBC Press, Vancouver-Toronto, Law and Society Series; Surender Singh Chauhan (2001), Biodiversity, Biopiracy and Biopolitics: The Global Perspective, Kalinga Publications, Delhi; Lakshmi Sarma, Biopiracy: Twentieth Century imperialism in the form of international agreements, 13 Temp. Int'l \& Comp. L. J. 107 (1999); Lorna Dwyer, Biopiracy, trade, and sustainable development, 19 Colo. J. Int'l Envtl. L. \& Pol'y 219 (2008); see generally Walid Abdegawad, La biopiraterie et le commerce des produits pharmaceutiques face aux droits des populations locales sur leurs savoirs traditionnels, in Le Médicament et la Personne: Aspects de Droit International, I. Moine-Dupuis (dir.), Litec, Paris, 2007, at 323; Walid Abdelgawad, Les contrats internationaux de bioprospection: moyen de protection de la biodiversité et des savoirs traditionnels ou instruments de biopiraterie, 22-1 Revue Québécoise de droit international 53 (2009).

${ }^{2}$ Convention on Biological Diversity; available at www.cbd.int/ doc/legal/cbd-en.pdf

${ }^{3}$ Nagoya Protocol; available at www.cbd.int/abs/doc/protocol/ nagoya-protocol-en.pdf

${ }^{4}$ The text of the Biological Diversity Act 2002 is published in The Gazette of India, Part II Section 1, February 5, 2003.

${ }^{5}$ Indian National Biodiversity Authority website (www.nbaindia .org/introduction.htm). For more details, see Surender Singh Chauhan, supra n. 1 at 33 .

${ }^{6}$ Many studies deal with these biopiracy cases, Vandana Shiva, supra n. 1 at 69; Ikechi. Mgbeoji, supra n. 1 at 15 and 147; Surender Singh Chauhan, supra n. 1 at 228; Lorna Dwyer, supra $\mathrm{n} .1$ at 227; Walid Abdegawad (la biopiraterie), supra n. 1 at 335; Shayana Kadidal, Subject-matter imperialism? Biodiversity, foreign prior art and the neem patent controversy, 37 J.L. \& Tech. 371 (1997); Fritz Dolder, Traditional knowledge and patenting: the experience of the neem fungicide and the hoodia cases, 26 Biotechnol. L. Rep. 583 (2007). 
and its Indian collaborators and the impact of a potential judicial condemnation of $B t$ Brinjal developers.

\section{ESTABLISHING THE FRAMEWORK OF THE BT BRINJAL CASE}

In its resolution adopted on 20 June $2011,{ }^{7}$ the National Biodiversity Authority of India (NBA) decided to "proceed legally" against Monsanto, its Indian partner Maharashtra Hybrid Seeds Company (Mahyco) - 26\% of which is owned by Monsantoand their Indian collaborators, the University of Agriculture Sciences (UAS) at Dharwad in north Karnataka (hereinafter UAS-Dharwad) and Sathguru Management Consultants Ltd, a private Indian company acting as a coordinator on behalf of USAID and Cornell University. The NBA's decision challenges the Indian legal system, because it will highlight the manner in which courts will interpret and implement the Biological Diversity Act in an area of growing concern. This biopiracy case is related to an important and sensitive field which threatens both material and spiritual interests of the local communities and farmers who are the holders of traditional knowledge on biological resources.

Brinjal, which is the Indian name of eggplant, has been cultivated in India by millions of farmers, who have developed 2,500 varieties. This plant, popular in Indian recipes, is also used as a religious offering in some areas of India.

The NBA decision charges these three entities with alleged violation of the Biological Diversity Act, "for accessing and using the local brinjal varieties for development of $B t$ brinjal without prior approval of the competent authorities (...)." ${ }^{8}$ According to the NBA secretary, "The authority has decided to proceed legally against Mahyco and Monsanto, and all other concerned to take the issue to its logical conclusion"9; consequently, $B t$ brinjal developers could face "criminal proceedings" for violation of the Biological Diversity Act, $2002 .{ }^{10}$ Recently, this decision was formally confirmed by NBA during its meeting held in New Delhi in August 2011. As an NBA senior official stated, "The NBA is now continuously moving forward in that direction." ${ }^{11}$

The NBA decision originated with a complaint (available at www.esgindia.org/campaigns/brinjal/ press/national-biodiversity-authority-prosecut.html) lodged by the Environment Support Group (ESG), a nongovernmental organization based in Bangalore, before the Karnataka Biodiversity Board on 15 February 2010. The Group had gathered and published many official documents regarding this case on its website. $^{12}$ After investigating the file, the Karnataka Biodiversity Board informed NBA on 28 May 2011 that, "six local varieties for development of $B t$ brinjal were accessed in the state by the two companies without prior approval from State Biodiversity Board/ National Biodiversity Authority" 13 and called for legal action. The Indian farmers' growing protests against $B t$ brinjal had encouraged the Minister of Environment to announce on February 2010, just before the ESG's complaint, a moratorium on $B t$ brinjal until there is a public consensus on health and safety issues. ${ }^{14}$

The crux of the matter in this case is a "sublicense agreement" 15 (available at www.esgindia.org/campaigns/ brinjal/press/national-biodiversity-authority-prosecut .html), dated 23 April 2005, in force between the three parties: Mahyco, UAS-Dharwad, and Sathguru. This tripartite agreement recited a common objective in development and delivery "of pro-poor varieties of insect tolerant $B t$. eggplant" ${ }^{16}$ - that is, genetically modified $B t$ brinjal. This transfer technology agreement was part of a U.S.-Indian public-private partnership, promoted by USAID and managed by Cornell University. This consortium, whose Indian coordinator is Sathguru, is intended to facilitate the development of bioengineered products in developing countries under the Agriculture Biotechnology Support Project II (ABSP-II).

In accordance with this agreement, Mahyco transferred the CrylAC gene technology (supplied by Monsanto) to the six local varieties provided by UAS-Dharwad by backcrossing. This technology was transferred by Mahyco to UAS (and also to the Tamil Nadu Agriculture University) as a royalty-free license to make it available "to resource-constrained farmers under the ABSPII project" ${ }^{17}$ in India.

\section{THE LEGAL ALLEGATIONS REGARDING VIOLATION OF THE BIOLOGICAL DIVERSITY ACT, 2002}

In its complaint before the Karnataka Biodiversity Board, ${ }^{18}$ ESG put forward the following four

${ }^{7}$ Available at www.nbaindia.org/docs/20th_Proceedings_10_ 08_2011.pdf at 7 .

${ }^{8}$ Ibid.

${ }^{9}$ Dinesh C. Sharma, "Heat on Monsanto for brinjal piracy," Mail Today, 12 August 2011.

${ }^{10}$ Priscilla Jebaraj, "NBA for action against BT brinjal biopiracy," The Hindu, 10 August 2011.

${ }^{11}$ Ibid.

${ }^{12} \mathrm{ESG}$ web site: www.esgindia.org/campaigns/brinjal/press/ national-biodiversity-authority-prosecut.html

${ }^{13}$ Letter from Karnataka Biodiversity Board to The Secretary, National Biodiversity Authority, dated 28 May 2011; available at www.esgindia.org/sites/default/files/campaigns/brinjal/press/ b-bt-brinjal-kbb-nba-biopiracy-submission.pdf

${ }^{14}$ Priscilla Jebaraj, supra n. 10.

${ }^{15}$ This agreement may be accessed at www.esgindia.org/sites/ default/files/campaigns/brinjal/press/d-uas-dharwad-mahycoagreement-2005-1-2005.pdf

${ }^{16}$ Preamble to the previously mentioned agreement. $I d . \mathrm{n}^{\circ}$ (e).

${ }^{17} \mathrm{Ibid}$, Preamble, $\mathrm{n}^{\circ}$ (e).

${ }^{18}$ Available at www.esgindia.org/sites/default/files/campaigns/ brinjal/press/esg-karbioboard-btbrinjal-petition-12021.pdf 
allegations of violations of the Biological Diversity Act by the contracting parties.

The first allegation is related to the violation of Sections 3 and 4 of the Act. Section 3 requires foreign companies or citizens who seek access to biological resources to obtain the prior approval of the NBA. The same requirement is stated in Section 4, in the case of a transfer of any research result related to biological resources to foreign companies or citizens. An exemption is provided by Section 5 (1), which holds that the prior approval of NBA is not required in the case of a "collaborative research project" involving Indian and foreign institutions under the conditions that such project (1) "be approved by the Central Government," and ii) "conform[] to the policy guidelines issued by the Central Government." 19 These Guidelines were published by the Ministry of Environment and Forests in November 2006. ${ }^{20}$

After examining the subject matter, the NBA concluded that "the said research project seems prima facie to fall outside the scope of guidelines issued by the Central Government." ${ }^{21}$ As a result, the three parties of the sublicense agreement had no right to an exemption under Section 5 (1), and thus should have obtained NBA approval. NBA expressly noted that it "has not received any application from any of the parties" 22 under Sections 3 or 4 . This first allegation based on the violation of Sections 3 and 4 seems to be the most convincing argument.

Second, ESG accused the contracting parties of failing to give prior notice to the Karnataka Biodiversity Board (KBB); this is mandatory under Section 7 in order to get biological resources "for commercial utilization." This allegation is relevant only if there is "commercial utilization" of Bt eggplant technology, which may not be the case for this sublicense agreement, which prima facie aims to transfer technology to UAS-Dharwad without commercial uses. This agreement provided that Mahyco, as a sublicensor, “... has agreed to provide access to the technology without any payment for such access." ${ }^{23}$ It grants to UAS-Dharwad "... a royalty-fee, not-for-profit sublicense" ${ }^{24}$ so as to develop or distribute to resource-constrained farmers "other than by sale" licensed domestic eggplant products. Thus, the sublicense agreement does not provide for commercial utilization of $B t$ eggplant technology.

However, this agreement has to be examined in the light of two factors. First, the disputed agreement is part of the ABSP II Project, which is defined as a project that focuses "on the safe and effective development and commercialization of bio-engineered products...in developing countries...." ${ }^{25}$ Second, as expressly mentioned in the sublicense agreement, Mahyco previously entered into agreement with Sathguru on 10 March 2005 the aim of which was to undertake the research and development of varieties of eggplant tolerant to fruit and shoot borer, "with a view to product commercialization or other distribu- tion in certain South-Asian and East Asian territories by Licensed ABSP II collaborators." ${ }^{26}$ These two aspects throw doubt on the real intention of the three parties to the disputed sublicense arrangement. For these reasons, further investigations must be launched to ascertain whether the $B t$ brinjal has been commercialized "in any manner" 27 by the parties when implementing the sublicense agreement. Additional information has been sought from the parties involved in the development of Bt brinjal, and appropriate action will be taken on the basis of this information, as was recently confirmed by the Minister of State for Environment and Forests, Ms. Jayanthi Natarajan, on 28 November $2011 .^{28}$

The third allegation is based on the violation of Section 41 (2), which provides that NBA and the State Biodiversity Board consult the Biodiversity Management Committee, the local biodiversity authority, "while taking any decision relating to the use of biological resource and knowledge associated with such resources occurring within the territorial jurisdiction of the Biodiversity Management Committee." This allegation is weak, however, for the reason that only the NBA and the State Biodiversity Board (KBB) are appointed under Section 41 (2) to consult the Biodiversity Management Committee - the three contracting parties in this case are not directly linked to this rule.

Fourth, it is alleged that the contracting parties, accused of having access to six local varieties of brinjal without the permission of the competent authorities, deprived the local communities of their right (recognized by the Biological Diversity Act) to equitable benefit sharing arising out of commercial use of these resources. This allegation is linked to the first one and requires that there be a prior violation of the rule related to the formal permission.

The three contracting parties' replies to these allegations were not convincing and seem to rely on a questionable legal basis. When contacted by the media, Monsanto denied the charges and argued that

\footnotetext{
${ }^{19}$ Section 5.3 of the Biological Diversity Act.

${ }^{20}$ These guidelines were published in The Gazette of India, Part II, Section 3, Sub-section (ii), 8 November 2006.

${ }^{21}$ Letter from NBA to Shri. H.S. Sugara IFS, Member Secretary of Karnataka Biodiversity Board, dated 25 April 2011; available at www.esgindia.org/sites/default/files/campaigns/brinjal/ press/b-bt-brinjal-kbb-nba-biopiracy-submission.pdf

${ }^{22}$ Ibid.

${ }^{23}$ Preamble of the sublicense agreement, supra $\mathrm{n} .16, \mathrm{n}^{\circ}(\mathrm{e})$.

${ }^{24}$ Provision 2.1 of the sublicense agreement. Id.

${ }^{25}$ Preamble of the sublicense agreement. $I d ., \mathrm{n}^{\circ}(\mathrm{b})$

${ }^{26}$ Ibid., $\mathrm{n}^{\circ}$ (f).

${ }^{27}$ Id. n. 21; available at www.esgindia.org/sites/default/ files/campaigns/brinjal/press/b-bt-brinjal-kbb-nba-biopiracysubmission.pdf

${ }^{28}$ Dinesh Singh Rawat, Legal action on violation of Bio-Diversity Act, ABC Live, 28 November 2011.
} 
it had not developed $B t$ brinjal but that it had been "developed by Mahyco, with CrylAC gene accessed from Monsanto, in collaboration with multiple public sector institutions," ${ }^{29}$ such as AUS-Dharwad. This argument is weak, as Monsanto owns 26\% of Mahyco's shares; in addition, both corporations are part of the joint venture, Mahyco Monsanto Biotech Limited, a company that introduced Monsanto's genetically modified cotton, $B t$ cotton, to India. It is also relevant that Mahyco and Monsanto are involved in the previously mentioned U.S.-Indian project (ABSP-II).

While disapproving of any violation of Biological Diversity Act, Mahyco ${ }^{30}$ claimed that UAS-Dharwad first initiated contact with Mahyco and provided it with the local varieties of brinjal to develop $B t$ brinjal, and that Mahyco merely introgressed the CrylAC gene into these varieties. Mahyco (supported by Sathguru ${ }^{31}$ ) also argued that it does not share any royalty fee when transferring this technology to UAS-Dharwad; moreover, Mahyco holds the view that the sublicense agreement does not stipulate any commercial use of gene technology provided by Mahyco to UAS-Dharwad. ${ }^{32}$ In its letter dated 25 April 2011, ${ }^{33}$ NBA observed that if the $B t$ gene was transferred by Mahyco to UAS after incorporating the CrylAC gene into the local variety of brinjal, Mahyco would infringe Section 3 of the Act, which requires prior approval. More information is needed from the parties to clarify this issue.

Lastly, UAS-Dharwad ${ }^{34}$ claimed that ABSPII project was initiated with-and approved by-the Department of Biotechnology, the Ministry of Science and Technology of the Government of India. It cited a list of permissions obtained from various competent Indian authorities. It is doubtful, however, that such permissions will fulfill the requirements of the Biological Diversity Act, which expressly designates NBA, the Karnataka Biodiversity Board, and the Biodiversity Management Committees as the competent authorities for access to and use of biodiversity resources in India. UAS-Dharwad has not mentioned any permission provided by these three bodies.

\section{WHAT MIGHT BE THE IMPACT OF THE BT BRINJAL CASE?}

The potential condemnation for biopiracy in the $B t$ brinjal case could undermine Monsanto's other request to access two varieties of Indian onion for potential hybridization, which is now under examination by the authorities. More broadly, it could threaten the development of Monsanto's hybrids seeds and genetically modified crops in India. It is relevant to refer to the current project, supported by the U.S. government, to introduce Nepal hybrid maize seeds produced by Monsanto. Protesters denounced this project as an attempt to conceal Monsanto's long-term plan to introduce its transgenic maize in Nepal. ${ }^{35}$ Another project threatened by the NBA decision is the current Mahyco plan to introduce $B t$ rice for commercial production.

Even the only authorized Monsanto genetically modified crop in India, $B t$ cotton, which contains the same gene (CrylAC) as the $B t$ brinjal, is now subject to restrictive measures. In fact, India has produced $B t$ cotton widely for the past 10 years, but recently, an increasing number of States have changed their attitude toward this kind of seed. The government of the Tamil Nadu announced last August 2011 it would not promote $B t$ cotton, and seven Indian states have already declared themselves free from transgenic crop trials. ${ }^{36}$ These measures were adopted after farmers' organizations and activists demonstrated against Monsanto $B t$ cotton. The demonstrators alleged that thousands of indebted farmers had committed suicide, victims of increasing quantities of inputs and facing higher prices for $B t$ cotton after the withholding of stocks from the market, in particular in Andhra Pradesh. ${ }^{37}$ The outcome of the $B t$ binjab case could also reinforce the development of alternatives to Monsanto's Bt genes, such as might come from enhanced funding of public agriculture research and increased utilization of the traditional knowledge of local communities.

By adopting this decision, for the first time, the NBA aims to issue a firm message to foreign agencies and their Indians collaborators: from now on, the practice of biopiracy in India might be prosecuted legally. Future developments will tell us what to expect from this new public policy.

\footnotetext{
${ }^{29}$ Dinesh C. Sharma, supra n. 9.

${ }^{30}$ Letter from Maharshtra Hybrid Seeds Company Limited (Mahyco) to the Addl. Principal Chief Conservator of Forests and Member Secretary Karnataka Biodiversity Board, dated 25 June 2010, and Letter from Maharshtra Hybrid Seeds Company Limited (Mahyco) to the Chief Conservator of Forests and Member Secretary Karnataka Board, dated 29 April 2011; available at www.esgindia.org/sites/default/files/campaigns/ brinjal/press/b-bt-brinjal-kbb-nba-biopiracy-submission.pdf

${ }^{31}$ Letter from Sathguru Management Consultants (P) Ltd. to Chief Conservator of Forests and Member Secretary, dated 21 April 2011; available at www.esgindia.org/sites/default/files/ campaigns/brinjal/press/b-bt-brinjal-kbb-nba-biopiracy-submission .pdf

${ }^{32}$ Ibid.

${ }^{33}$ Letter from NBA to Shri. H.S. Sugara IFS, Member Secretary of Karnataka Biodiversity Board dated 25 April 2011, supra n. 21.

${ }^{34}$ Letter from University of Agricultural Science, Dharma to Chief Conservator of Forests and member Secretary Karnataka Biodiversity Board, dated 17 May 2011; available at www .esgindia.org/sites/default/files/campaigns/brinjal/press/b-btbrinjal-kbb-nba-biopiracy-submission.pdf

${ }^{35}$ Nepali Times, 4 November 2011.

${ }^{36}$ New Indian Express, 13 August 2011.

${ }^{37}$ Nepali Times, 4 November 2011. Adde, The Hindu, 17 June
} 2006. 